\title{
U.S. and Asia Pacific Equity Markets Causality Test
}

\author{
Liang Ding \\ Business Department, Alvernia University \\ Reading, PA, 19607, USA
}

\begin{abstract}
This paper focuses on the causality relation between US and the several Asia-pacific markets (Japan, China, Hong Kong, Taiwan, Singapore, Korea, and Indonesia). We check the causality of the co-movement among the markets across Pacific by using Granger-Causality test, VAR, and event studying on unexpected high volatile period. Our tests show that U.S. and Japan have strong influence to other Asia-pacific markets. Comparing with US market, Japan market has high correlation but low granger causality relation with other Asia markets. However, comparing with its strong business relation with other countries, Chinese equity market appears very low correlation with other Asia markets and US market. Hong Kong, Taiwan, Singapore, Korea, and Indonesia markets show relative strong correlation and weak granger causality relation among each other.
\end{abstract}

Keywords: Asia-pacific, Equity markets, Causality tests, VAR

\section{Introduction}

The interrelationship between the national equity markets has been investigated by a considerable amount of works. Since the economics of different countries are inevitable interwoven through international trade and investment, people are more commonly to believe that movements of stock prices across countries are correlated.

Among the co-movement, one of major focus is raised by the contagion of the market crisis. Several market crises, i.e. US 1987, East Asia 1997, and Russian 1999 crisis, gave the researchers great opportunity to look at the contagion of the crisis. Especially after the crash of October 1987, people realize that the world market is so integrated that the larger markets has a strong influence on other smaller markets.

The interests from market participants and academia on the Asian Pacifica markets have been raised since East Asian financial crisis 1997. The nations in that area have been well considered as the successful models of emerging countries. The economy sizes and international trading volumes in the area have been significantly increased since 1990. The high investment return has attracted huge amount foreign investment. However, the financial crisis in this area not only brought disaster to the local, but also brought strong negative impact on the world. Since then, people always have interests to know how the relationship of financial markets in this area with the rest of the world would be.

Different with normal believe, some recent researches on contagion find that there is no contagion between national markets but interdependence or called co-movement. Among many researchers, Cha and Cheung (1998) use four Asian stocks information to show the impact of US and Japan market on Asia market by using a tri-variate vector autoregression model, and find strong evident of co-movements among world equity markets with the US market playing the leading role.

The focus of this paper is on the causality relation between US and the several Asia-pacific markets (Japan, China, Hong Kong, Taiwan, Singapore, Korea, and Indonesia). Different with pervious studies, we are interested in checking the causality of the co-movement among the market across Pacifica by using Granger-Causality test, VAR, and event studying on unexpected high volatile period.

Similar with Cha and Cheung's (1998) result, we find that US and Japan markets are more likely to cause the fluctuations of other Asian-pacific markets. In addition, the tests in this paper show some evidences that the role of US market is relatively more significant than Japan market by using VAR models.

Some markets like Hong Kong, Singapore, Taiwan, Korea, and Indonesia, have relative strong correlation with each other. However, no strong evidence shows the causality relation among any of those markets. This result is consistent with some recent researches (Hyde et al, 2007; Kleimeier et al, 2003; Forbes and Rigobon, 2002), which show the co-movement among those markets.

Different with the results of Tan (2007), which find some weak evidence of the cointegration between China A share (domestic market) with US market, the test in this paper finds that there is no causality between the two markets. This finding is a surprise since China and US economy, especially in terms of international trade, are so 
closing connected. One possible explanation would be that the financial market of China, especially the equity market, is still not directly open to the international investors.

The rest of paper is organized as follows. Section 2 describes the data. Section 3 describe the methodology employed and report the empirical result. Section 4 concludes the paper.

\section{Data}

This study includes the eight markets. All data come from Yahoo Finance (Note 1). Based on the available of the data, we get the daily open and the close index price for the each sample period. China is started from Jan 3 , 2000 (Shanghai Composite); Hong Kong (Jan 2, 1990) (Hang Seng); Taiwan (July 2, 1997) (Taiwan Weighted); Singapore (June 9, 1992) (Straits Times); Korea (July 1, 1997) (Seoul Composite); and Indonesia (July 1, 1997) (Jakarta Composite). In addition, we get US (S\&P 500) and Japan (Nikkei 225) market in the corresponding periods. Then, we calculate the daily stock index return based on the open and the close of each index.

Table 1 show the basic market information of each market. In term of market capitalization and the number of firm listed, the New York stock exchange is the titan comparing with the other Asian markets. Japan is still leading in the Asia-pacific, while its Asian partners are growing very quickly. In 1991, Tokyo stock market has market capitalization \$2.9 trillion, and 1641 firms; Hong Kong has \$0.38 trillion, 333 firms; Korea \$0.098 trillion, 686 firms; Singapore $\$ 0.15$ trillion, 157 firms; Taiwan $\$ 0.12$ trillion, 221 firms (Cha and Cheung, 1998). In table 1, we find significant increase for Hong Kong, Korea, Singapore, and Taiwan market. And especially, China market also had increased dramatically since 1990. In the most recently data, China equity market is one of the largest markets in Asia. In all, we find the Japan market is losing its advance to other Asian markets. However, since it is still the top market in Asian, Japan market shows, in some evidences from the later tests, that Japan market has strong impact on the other Asia-pacific market.

\section{Market Causality Tests}

The interest of this paper is to check the causality relation among those markets. We have no doubt about the market co-movement among the pacific. The question is whether the causality is running from one-way to the other or could run from each way.

We test the null: the return of market A does not Granger cause the return of market B.

From the Granger Causality view, we can use the following model:

$$
\begin{gathered}
y_{t}=\alpha_{0}+\alpha_{1} y_{t-1}+\ldots+\alpha_{l} y_{t-l}+\beta_{1} x_{t-1}+\ldots+\beta_{l} x_{t-l}+\varepsilon_{t} \\
x_{t}=\alpha_{0}+\alpha_{1} x_{t-1}+\ldots+\alpha_{l} x_{t-l}+\beta_{1} y_{t-1}+\ldots+\beta_{l} y_{t-l}+u_{t}
\end{gathered}
$$

$\mathrm{y}_{\mathrm{t}}$ is the return of market $\mathrm{A}, \mathrm{x}_{\mathrm{t}}$ is the return of market $\mathrm{B}, \mathrm{L}$ is the lag length.

Table 2 report the pairwise Granger Causality tests of each pair of market using two lags.

From the pairwise Granger Causality tests, we find that US market index return granger cause the index return of Japan, Hong Kong, Taiwan, Singapore, Korea, and Indonesia. Japan also granger cause Hong Kong, Singapore. Hong Kong granger causes Singapore, Korea and Indonesia. Among any two of Singapore, Korea and Indonesia, the granger causality runs from each way to the other. China market is an exception, which does not granger cause any other market, nor is granger caused by any other market. This is a little bit surprise given the size of china market and the international trade volume.

When we check the causality from the other way, we find no any Asian countries granger cause the US market. All markets except US does not granger cause the index return of Japan market. The countries with smaller market capitalization are more likely to be impacted by the other big market capitalization countries.

We check the correlation among the index return of each counties with pairwise sample. Singapore and Hong Kong market has the highest correlation (0.4490), while US and China has the lowest correlation (0.0001) (see table 3). Japan market, comparing with US market, has a stronger correlation with any other Asia markets. Next to Indonesia, similar with result of granger causality test, China market has the lowest correlation with other markets. Hong Kong, Taiwan, Singapore, and Korea have relative high correlation with other markets.

Since the correlation tests can not show the causality among each market, we further check the correlation in the extreme fluctuation periods. When market A has abnormal return (Note 2) increases, it increases the correlation with the market B. However, when the market B gets its abnormal return, the correlation with A do not increase. We define that the fluctuation of market $\mathrm{A}$ has more impact on the market $\mathrm{B}$ than the fluctuation of market $\mathrm{B}$ on market A. If we find the correlation increase in the similar strength between market A and market B during the periods that each market has similar degree of fluctuation, we define that the interaction between the two 
markets runs from each other.

For each market, we group the periods of the abnormal return with at least one standard deviation, two standard deviations, and three standard deviations, and calculate the correlation between any two markets in the periods.

Similar with full sample period correlation test, Singapore and Hong Kong have highest correlation between each other with either market increasing the abnormal return. As shown in table 4, when US market increase the deviation from the mean, the correlation with Asia market generally increasing. When other Asia market increases the fluctuation, the correlation with US market increase to some extent, but the pattern is not consistent. In addition, the correlation is higher when US are fluctuation increase comparing with that when Asia market go abnormal. Japan market has relatively strong correlation with other Asia market comparing with US market. China has a relative strong correlation with Hong Kong when the abnormal return increase in either market. The correlation changes of China and US market show different pattern. When China market experiences high fluctuation, the increases of the correlation between US and China are higher than the correlation increases in the periods that US market experiences high fluctuation. This pattern does not show in the Granger causality tests.

We further check the dynamic impact of each market by Vector autoregression model (VAR). In general, an m-th order VAR model for an $n^{*} 1$ vector $\mathrm{Y}$ is written as:

$$
Y_{t}=\alpha+\sum_{j=1}^{m} \beta_{j} Y_{t-j}+\sum_{j=1}^{m} \phi_{j} X_{t-j}+e_{t}, \quad t=1, \ldots, T
$$

We run the VAR model with all markets information to check the interaction among all markets.

Table 5 shows the result of VAR tests for all markets information by using 2 lags. In general, each Asian market is influenced at least by one of US, Japan, or both, plus its domestic market. Different with the previous test, Indonesia is an exception in the VAR test. US and Japan markets seem have no impact on Indonesia market. US market show the same pattern in the granger causality test that no Asian markets have significant impact on its index return.

To focus more on the interaction among US, Japan, and other Asian-pacific market, similar with Cha and Cheung (1998) test, we use a tri-variate VAR model for each Asian-pacific market. The model tests the interaction among US, Japan, and the domestic market for each county.

In the tri-variate VAR model for China market, only the coefficient of one lag domestic return is significant. U.S. and Japan's impact on China are not significant. U.S. and Japan are significant for Hong Kong market. Taiwan, Korea, and Indonesia market is significant impacted by US and local market. Singapore market is influenced by US, Japan and local market.

In general, U.S. and Japan have strong impact on the Asia-pacific market. The Asia-pacific markets are also significant impacted on the one-lag domestic index return.

\section{Conclusion}

By using several tests, this paper empirically investigate the causality among US and Asia-pacific markets, Japan, China, Hong Kong, Taiwan, Singapore, Korea, and Indonesia.

Similar with many other researches, this paper provide additional evidence in testing that US and Japan have strong influence to other Asia-pacific markets. US market, as the largest market, leads the fluctuation of the world wide equity markets. Since Japan market is the largest in Asia, the geographic advance makes it an important player in Asia-pacific market. Comparing with US market, Japan market has high correlation and lower granger causality relation with other Asia markets, which shows its relative weak impact on Asia markets.

China market has increased rapidly in recent year. The quick expansion makes China as one of the largest markets in Asia-pacific. Comparing with its strong business relation with other countries, its equity market appears very low correlation with other Asia markets and US market.

Hong Kong, Taiwan, Singapore, Korea, and Indonesia markets show relative strong correlation and weak granger causality relation among each other. Meanwhile, the bigger markets, such as US, Japan, appear strong impacts on them. The tests show the granger causality are more likely run one-way from bigger markets to smaller markets.

One possible explanation for the different relation of China and other Asia-pacific countries to US and Japan is the openness degree of each country. I.e. Chinn and Ito (2007) identify the openness degree of each country. In their index, the country openness number of US is 111 (rank 1), Japan 158 (rank 15), Hong Kong 532 (rank 81), 
Indonesia 536 (rank 83), Korea 542 (rank 84), Singapore 576 (rank 91), while China 924 (Rank 165). Further researches could be found out the reasons that cause the different causality relation among Asia markets and US market.

\section{References}

Baekin Cha and Yan-Leung Cheung. (1998). The impact of the US and the Japanese equity markets on the emerging Asia-pacific equity market. Asia-pacific Financial Markets, 5.

G. Tan. (2007). Are Chinese stock markets increasing integration with other markets in the greater China region and other major markets?, Working paper.

Kristin Forbes and Roberto Rigobon. (2002). No Contagion, only interdependence: measuring stock market comovement, Journal of Finance, VOL. LVII, NO. 5.

Menzie D. Chinn and Hiro Ito. (2007). A new measure of financial openness, Working paper.

Stefanie Kleimeier, Thorsten Lehnert and Willem F.C. Verschoor. (2003). Contagion versus interdependence: A re-examination of Asian-Crisis stock market comovements, Working paper.

Stuart Hyde, Don Bredin and Nghia Nguyen. (2007). Correlation dynamics between Asia-Pacific, EU and US stock returns, Working paper.

\section{Notes}

Note 1. Based on the availability of data, we use all availably data for each stock market. Due to the quality of data, some early records of some market show open price and close price are same. We delete those observations.

Note 2. The abnormal return refers to the difference between return and mean.

Table 1. Description of US and Asian-Pacific Markets

\begin{tabular}{|l|c|c|c|c|c|c|c|c|}
\hline Country & $\begin{array}{c}\text { US } \\
(2006) \\
\text { New York) }\end{array}$ & $\begin{array}{c}\text { Japan } \\
(2006) \\
(\text { Tokyo) }\end{array}$ & $\begin{array}{c}\text { China } \\
(2008) \\
(\text { Shanghai) }\end{array}$ & $\begin{array}{c}\text { Hong Kong } \\
(2007)\end{array}$ & $\begin{array}{c}\text { Taiwan } \\
(2007)\end{array}$ & $\begin{array}{c}\text { Singapore } \\
(2007)\end{array}$ & $\begin{array}{c}\text { Korea } \\
(2006)\end{array}$ & $\begin{array}{c}\text { Indonesia } \\
(2007)\end{array}$ \\
\hline $\begin{array}{l}\text { Market } \\
\text { capitalization } \\
\text { (Millions) }\end{array}$ & $\$ 25,000,000$ & $\$ 4,630,000$ & $\$ 3,831,839$ & $\$ 2,636,124$ & $\$ 725,170$ & $\$ 559,739$ & $\$ 1,260,000$ & $\$ 135,569$ \\
\hline $\begin{array}{l}\text { No of listed } \\
\text { companies }\end{array}$ & 2,805 & 2391 & 850 & 1049 & 680 & 722 & 1694 & 383 \\
\hline $\begin{array}{l}\text { Mean of } \\
\text { index return }\end{array}$ & 0.000213 & -0.000636 & 0.000318 & 0.0000789 & -0.001877 & -0.000444 & -0.00063 & 0.000175 \\
\hline Std. Dev. & 0.010032 & 0.013119 & 0.014375 & 0.012488 & 0.013328 & 0.011422 & 0.016971 & 0.016707 \\
\hline Observations & 4478 & 4363 & 1948 & 4500 & 2620 & 3886 & 2626 & 2565 \\
\hline
\end{tabular}


Table 2. Pairwise Granger Causality Tests

\begin{tabular}{|c|c|c|c|c|c|c|c|c|c|c|c|c|c|c|c|c|}
\hline & \multicolumn{2}{|l|}{ us } & \multicolumn{2}{|l|}{ Japan } & \multicolumn{2}{|l|}{ China } & \multicolumn{2}{|c|}{ Hong Kong } & \multicolumn{2}{|l|}{ Taiwan } & \multicolumn{2}{|c|}{ Singapore } & \multicolumn{2}{|l|}{ Korea } & \multicolumn{2}{|c|}{ Indonesia } \\
\hline & F-Stat & Prob & F-Stat & Prob & F-Stat & Prob & F-Stat & Prob & F-Stat & Prob & F-Stat & Prob & F-Stat & Prob & F-Stat & Prob \\
\hline us & & & 55,03 & $0.000^{\circ}$ & 1.648 & 0.192 & 21.06 & $0.000^{\circ}$ & 28.363 & $0.000^{\circ}$ & 9.745 & $0.000^{\circ}$ & 3.669 & $0.025^{\circ}$ & 21.31 & $0.000^{\circ}$ \\
\hline Ip & 2.201 & 0.110 & & & 0.859 & 0.423 & 7.017 & $0.001^{*}$ & 1.027 & 0.358 & 3.265 & $0.038^{\circ}$ & 2.058 & 0.127 & 0.147 & 0.863 \\
\hline $\mathrm{CH}$ & 0.239 & 0.787 & 0.507 & 0.602 & & & 1.438 & 0.237 & 1.987 & 0.137 & 0.862 & 0.422 & 0.539 & 0.583 & 0.329 & 0.719 \\
\hline$H K$ & 0.641 & 0.526 & 0.460 & 0.631 & 0.409 & 0.664 & & & 1.013 & 0.363 & 13.43 & $0.000^{\circ}$ & 3.554 & $0.028^{*}$ & 7.747 & $0.000^{\circ}$ \\
\hline TW & 0.573 & 0.563 & 0.396 & 0.672 & 1.900 & 0.149 & 1.250 & 0.286 & & & 1.259 & 0.284 & 0.153 & 0.857 & 0.286 & 0.751 \\
\hline SG & 1.248 & 0.287 & 1.631 & 0.195 & 0.110 & 0.895 & 0.851 & 0.426 & 3.857 & $0.021^{\circ}$ & & & 6.027 & $0.002^{*}$ & 4.137 & $0.016^{\circ}$ \\
\hline KO & 0.669 & 0.512 & 1.039 & 0.353 & 0.970 & 0.379 & 1.652 & 0.191 & 0.127 & 0.880 & 4.518 & $0.011^{*}$ & & & 9.328 & $0.000^{\circ}$ \\
\hline IN & 1075 & 0.341 & 0.389 & 0.677 & 0.299 & 0.741 & 2717 & 0.066 & 2.276 & 0.102 & 9.928 & $0.000^{\circ}$ & 3.201 & $0.040^{\circ}$ & & \\
\hline
\end{tabular}

P-value* significant at 5\%

Table 3. Correlation Tests (Pairwise sample)

\begin{tabular}{|l|l|l|l|l|l|l|l|l|}
\hline & US & JAPAN & CHINA & HK & TAIWAN & SINGAPORE & KOREA & INDONESIA \\
\hline US & 1 & 0.114272 & 0.000151 & 0.126147 & 0.092182 & 0.139394 & 0.097701 & 0.023276 \\
\hline JAPAN & 0.114272 & 1 & 0.085083 & 0.278012 & 0.161384 & 0.240971 & 0.315479 & 0.192097 \\
\hline CHINA & 0.000151 & 0.085083 & 1 & 0.167291 & 0.03292 & 0.097987 & 0.073739 & 0.103209 \\
\hline HK & 0.126147 & 0.278012 & 0.167291 & 1 & 0.213819 & 0.449048 & 0.260727 & 0.267429 \\
\hline TAIWAN & 0.092182 & 0.161384 & 0.03292 & 0.213819 & 1 & 0.227913 & 0.257908 & 0.113723 \\
\hline SINGAPORE & 0.139394 & 0.240971 & 0.097987 & 0.449048 & 0.227913 & 1 & 0.289347 & 0.346493 \\
\hline KOREA & 0.097701 & 0.315479 & 0.073739 & 0.260727 & 0.257908 & 0.289347 & 1 & 0.174212 \\
\hline INDONESIA & 0.023276 & 0.192097 & 0.103209 & 0.267429 & 0.113723 & 0.346493 & 0.174212 & 1 \\
\hline
\end{tabular}


Table 4. Event Correlation tests

\begin{tabular}{|c|c|c|c|c|c|c|c|c|c|}
\hline & & US & JAPAN & CHINA & HK & TAIWAN & SINGAPORE & KOREA & INDONESIA \\
\hline full & US & 1 & 0.114272 & 0.000151 & 0.126147 & 0.092182 & 0.139394 & 0.097701 & 0.023276 \\
\hline 1 std & US & 1 & 0.175467 & -0.02926 & 0.222552 & 0.118893 & 0.211248 & 0.136034 & 0.039566 \\
\hline $2 s t d$ & US & 1 & 0.110029 & -0.05552 & 0.231586 & 0.145137 & 0.253675 & 0.116549 & 0.037541 \\
\hline 3std & US & 1 & 0.146227 & -0.00597 & 0.260677 & 0.398921 & 0.285856 & 0.221767 & -0.07907 \\
\hline full & JAPAN & 0.114272 & 1 & 0.085083 & 0.278012 & 0.161384 & 0.240971 & 0.315479 & 0.192097 \\
\hline $1 \mathrm{std}$ & JAPAN & 0.157442 & 1 & 0.165746 & 0.426186 & 0.254722 & 0.369638 & 0.429893 & 0.310836 \\
\hline $2 s t d$ & JAPAN & 0.157663 & 1 & 0.266154 & 0.554661 & 0.245601 & 0.466603 & 0.50295 & 0.409366 \\
\hline 3std & JAPAN & 0.084713 & 1 & 0.579124 & 0.659556 & 0.088465 & 0.531272 & 0.486283 & 0.486668 \\
\hline full & CHINA & 0.000151 & 0.085083 & 1 & 0.167291 & 0.03292 & 0.097987 & 0.073739 & 0.103209 \\
\hline 1 std & CHINA & 0.012429 & 0.154395 & 1 & 0.297978 & 0.043287 & 0.178885 & 0.130974 & 0.231333 \\
\hline $2 s t d$ & CHINA & 0.031493 & 0.185422 & 1 & 0.284633 & 0.077066 & 0.30473 & 0.129887 & 0.39672 \\
\hline 3std & CHINA & 0.243943 & 0.329864 & 1 & 0.490472 & 0.243133 & 0.465649 & 0.401202 & 0.465855 \\
\hline full & HK & 0.126147 & 0.278012 & 0.167291 & 1 & 0.213819 & 0.449048 & 0.260727 & 0.267429 \\
\hline $1 s t d$ & HK & 0.174344 & 0.510602 & 0.2644 & 1 & 0.359333 & 0.701498 & 0.580494 & 0.372317 \\
\hline $2 s t d$ & HK & 0.220233 & 0.435042 & 0.31567 & 1 & 0.296831 & 0.61627 & 0.30175 & 0.465092 \\
\hline 3std & HK & 0.205134 & 0.446636 & 0.225041 & 1 & 0.253689 & 0.609128 & 0.102404 & 0.580843 \\
\hline full & TAIWAN & 0.092182 & 0.161384 & 0.03292 & 0.213819 & 1 & 0.227913 & 0.257908 & 0.113723 \\
\hline $1 \mathrm{std}$ & TAIWAN & 0.13404 & 0.187825 & 0.024651 & 0.290975 & 1 & 0.319006 & 0.344766 & 0.162479 \\
\hline $2 s t d$ & TAIWAN & 0.126586 & 0.19417 & 0.099128 & 0.339219 & 1 & 0.291827 & 0.466543 & 0.026243 \\
\hline $3 s t d$ & TAIWAN & 0.015819 & 0.021136 & -0.09914 & 0.205174 & 1 & 0.141619 & 0.608841 & -0.17315 \\
\hline full & SINGAPORE & 0.139394 & 0.240971 & 0.097987 & 0.449048 & 0.227913 & 1 & 0.289347 & 0.346493 \\
\hline $1 \mathrm{std}$ & SINGAPORE & 0.198606 & 0.352189 & 0.168308 & 0.609484 & 0.301694 & 1 & 0.378509 & 0.444445 \\
\hline $2 s t d$ & SINGAPORE & 0.273181 & 0.419516 & 0.230849 & 0.741312 & 0.404275 & 1 & 0.387605 & 0.545179 \\
\hline 3std & SINGAPORE & 0.40415 & 0.51203 & 0.258163 & 0.84945 & 0.459869 & 1 & 0.390696 & 0.675616 \\
\hline full & KOREA & 0.097701 & 0.315479 & 0.073739 & 0.260727 & 0.257908 & 0.289347 & 1 & 0.174212 \\
\hline 1 std & KOREA & 0.126605 & 0.392065 & 0.096736 & 0.332147 & 0.295416 & 0.358975 & 1 & 0.207781 \\
\hline $2 s t d$ & KOREA & 0.071907 & 0.384037 & 0.272402 & 0.335019 & 0.208557 & 0.455844 & 1 & 0.24353 \\
\hline $3 s t d$ & KOREA & 0.156929 & 0.437186 & 0.302514 & 0.266848 & 0.245021 & 0.448351 & 1 & 0.287768 \\
\hline full & INDONESIA & 0.023276 & 0.192097 & 0.103209 & 0.267429 & 0.113723 & 0.346493 & 0.174212 & 1 \\
\hline 1std & INDONESIA & 0.033064 & 0.286289 & 0.207349 & 0.376884 & 0.210034 & 0.492192 & 0.237882 & 1 \\
\hline $2 \mathrm{std}$ & INDONESIA & 0.043964 & 0.305862 & 0.137221 & 0.489076 & 0.207646 & 0.641334 & 0.252257 & 1 \\
\hline 3std & INDONESIA & -0.01631 & 0.319827 & 0.339441 & 0.595305 & 0.37041 & 0.72225 & 0.277341 & 1 \\
\hline
\end{tabular}


Table 5. Vector Autoregression Estimates

\begin{tabular}{|c|c|c|c|c|c|c|c|c|}
\hline & US & Japan & China & HK & Taiwan & Singapore & Korea & Indonesia \\
\hline \multirow[t]{2}{*}{ US(-1) } & -0.04273 & $0.11942 *$ & 0.029725 & $\begin{array}{l}-0.03291 \\
\end{array}$ & $-0.23661^{*}$ & $-0.09757^{*}$ & $-0.241 *$ & 0.045794 \\
\hline & {$[-1.34117]$} & [ 3.91142] & [ 0.76530] & {$[-1.15989]$} & {$[-6.72667]$} & {$[-3.78499]$} & {$[-6.29945]$} & [ 1.34907] \\
\hline \multirow[t]{2}{*}{ US(-2) } & -0.02202 & 0.008865 & 0.018362 & $0.10722 *$ & 0.069214 & 0.043093 & 0.023239 & 0.011269 \\
\hline & {$[-0.68201]$} & [ 0.28644] & [ 0.46639] & [ 3.72759] & [ 1.94114] & [ 1.64918] & [ 0.59923] & [ 0.32749$]$ \\
\hline \multirow[t]{2}{*}{ Japan(-1) } & -0.04329 & $-0.13313^{*}$ & $-0.09785^{*}$ & $-0.11747^{*}$ & -0.05296 & $-0.08884 *$ & $-0.13976^{*}$ & -0.02085 \\
\hline & [-1.12679] & {$[-3.61594]$} & {$[-2.08905]$} & {$[-3.43281]$} & {$[-1.24861]$} & {$[-2.85794]$} & {$[-3.02927]$} & {$[-0.50923]$} \\
\hline \multirow[t]{2}{*}{ Japan(-2) } & 0.001207 & -0.00763 & -0.05106 & -0.05861 & 0.011127 & -0.00963 & -0.04993 & 0.009592 \\
\hline & {$[0.03460]$} & {$[-0.22810]$} & {$[-1.20039]$} & {$[-1.88618]$} & [ 0.28885] & {$[-0.34126]$} & {$[-1.19179]$} & [ 0.25804$]$ \\
\hline \multirow[t]{2}{*}{ China(-1) } & 0.033806 & -0.03528 & $-0.0805^{*}$ & -0.01097 & 0.030594 & 0.031437 & 0.014711 & 0.043337 \\
\hline & [ 1.31241$]$ & {$[-1.42918]$} & {$[-2.56327]$} & {$[-0.47803]$} & [ 1.07565] & [ 1.50821$]$ & [ 0.47553] & [ 1.57887] \\
\hline \multirow[t]{2}{*}{ China(-2) } & -0.01153 & 0.020379 & 0.002152 & 0.030764 & 0.024976 & 0.026714 & 0.02553 & 0.020819 \\
\hline & {$[-0.45716]$} & [0.84320] & [ 0.06999] & [ 1.36956$]$ & [ 0.89697] & [ 1.30915$]$ & [ 0.84299] & [ 0.77478] \\
\hline \multirow[t]{2}{*}{$\mathrm{HK}(-1)$} & -0.05017 & -0.04221 & -0.02317 & -0.02711 & 0.067592 & $-0.08057^{*}$ & 0.026473 & -0.07882 \\
\hline & [-1.14837] & {$[-1.00793]$} & {$[-0.43488]$} & {$[-0.69651]$} & [ 1.40109] & {$[-2.27895]$} & [ 0.50453] & {$[-1.69295]$} \\
\hline \multirow[t]{2}{*}{$\mathrm{HK}(-2)$} & -0.06601 & 0.013405 & -0.04419 & -0.01807 & 0.063676 & 0.004917 & 0.048967 & -0.03219 \\
\hline & [-1.54339] & [ 0.32702$]$ & {$[-0.84745]$} & {$[-0.47429]$} & [ 1.34828] & [ 0.14205$]$ & [ 0.95328] & {$[-0.70619]$} \\
\hline \multirow[t]{2}{*}{ Taiwan(-1) } & 0.028847 & -0.04214 & -0.00935 & -0.01243 & $-0.14162 *$ & -0.02585 & 0.015597 & -0.02137 \\
\hline & [0.91025] & {$[-1.38741]$} & {$[-0.24187]$} & {$[-0.44021]$} & {$[-4.04724]$} & {$[-1.00816]$} & [ 0.40982] & {$[-0.63269]$} \\
\hline \multirow[t]{2}{*}{ Taiwan(-2) } & 0.011975 & 0.003504 & 0.014195 & 0.017641 & 0.021086 & -0.00416 & -0.00055 & -0.05327 \\
\hline & [ 0.38489] & [ 0.11750$]$ & [ 0.37421] & [ 0.63655] & [ 0.61377] & {$[-0.16539]$} & {$[-0.01475]$} & {$[-1.60668]$} \\
\hline \multirow[t]{2}{*}{ Singapore(-1) } & -0.05919 & 0.078711 & -0.02001 & 0.081398 & 0.05081 & 0.061599 & 0.05949 & 0.002403 \\
\hline & {$[-1.26453]$} & [ 1.75444$]$ & {$[-0.35053]$} & [ 1.95211$]$ & [ 0.98300] & [ 1.62621$]$ & [ 1.05821] & [ 0.04818] \\
\hline \multirow[t]{2}{*}{ Singapore(-2) } & 0.053469 & 0.003573 & 0.050919 & 0.051213 & -0.01053 & -0.04727 & 0.026512 & 0.051466 \\
\hline & [ 1.18262$]$ & {$[0.08247]$} & {$[0.92370]$} & [ 1.27165$]$ & {$[-0.21101]$} & {$[-1.29190]$} & [ 0.48827] & [ 1.06827] \\
\hline \multirow[t]{2}{*}{ Korea(-1) } & 0.053024 & 0.036202 & 0.053656 & 0.023008 & 0.014583 & -0.00514 & -0.04543 & 0.03845 \\
\hline & [ 1.70522$]$ & [ 1.21475$]$ & [ 1.41527] & {$[0.83068]$} & [ 0.42472] & {$[-0.20429]$} & {$[-1.21643]$} & [ 1.16044] \\
\hline \multirow[t]{2}{*}{ Korea(-2) } & -0.01071 & -0.04254 & 0.023572 & -0.04806 & -0.02402 & -0.0218 & $-0.08409 *$ & 0.007451 \\
\hline & {$[-0.34647]$} & {$[-1.43580]$} & {$[0.62536]$} & {$[-1.74538]$} & {$[-0.70349]$} & {$[-0.87131]$} & {$[-2.26489]$} & [ 0.22618$]$ \\
\hline \multirow[t]{2}{*}{ Indonesia(-1) } & 0.025937 & 0.013658 & 0.025884 & -0.02642 & -0.03892 & 0.005608 & 0.012907 & $0.069888^{*}$ \\
\hline & [ 0.81023] & [ 0.44518$]$ & [ 0.66318] & {$[-0.92635]$} & {$[-1.10096]$} & [ 0.21651] & [ 0.33573] & [ 2.04883] \\
\hline \multirow[t]{2}{*}{ Indonesia(-2) } & 0.03483 & -0.01052 & 0.008215 & -0.02742 & -0.05517 & 0.023375 & -0.06401 & -0.01563 \\
\hline & [ 1.10551] & {$[-0.34834]$} & [ 0.21385] & {$[-0.97717]$} & {$[-1.58590]$} & [ 0.91685] & {$[-1.69182]$} & {$[-0.46554]$} \\
\hline \multirow[t]{2}{*}{ C } & -0.00028 & $-0.00083^{*}$ & $-4.46 \mathrm{E}-05$ & -0.00057 & $-0.00171 *$ & $-0.00103^{*}$ & -0.00033 & 0.000459 \\
\hline & {$[-0.77525]$} & {$[-2.42076]$} & {$[-0.10221]$} & {$[-1.80268]$} & [-4.33168] & {$[-3.55428]$} & {$[-0.76487]$} & [ 1.20569$]$ \\
\hline R-squared & 0.017161 & 0.040608 & 0.015894 & 0.039037 & 0.0803 & 0.049913 & 0.067367 & 0.015551 \\
\hline Adj. R-squared & 0.001607 & 0.025424 & 0.00032 & 0.023829 & 0.065745 & 0.034877 & 0.052607 & $-2.9 \mathrm{E}-05$ \\
\hline Sum sq. resids & 0.12279 & 0.112787 & 0.182535 & 0.097427 & 0.14971 & 0.080402 & 0.1771 & 0.139421 \\
\hline F-statistic & 1.10331 & 2.674506 & 1.02055 & 2.566884 & 5.516974 & 3.319585 & 4.564214 & 0.99815 \\
\hline Log likelihood & 3184.112 & 3227.789 & 2980.328 & 3303.038 & 3082.225 & 3401.759 & 2995.867 & 3118.824 \\
\hline Akaike AIC & -6.1617 & -6.24667 & -5.76523 & -6.39307 & -5.96347 & -6.58513 & -5.79546 & -6.03468 \\
\hline Schwarz SC & -6.08008 & -6.16506 & -5.68361 & -6.31145 & -5.88186 & -6.50352 & -5.71385 & -5.95306 \\
\hline \multicolumn{9}{|c|}{ Sample (adjusted): 1/06/2000 3/14/2008 } \\
\hline \multicolumn{9}{|c|}{ Included observations: 1028 after adjustments } \\
\hline \multicolumn{9}{|c|}{ t-statistics in [ ] , P-value* significant at 5\% } \\
\hline
\end{tabular}


Table 6. Vector Autoregression Estimates

\begin{tabular}{|l|l|l|l|l|l|l|}
\hline & China & HK & Taiwan & Singapore & Korea & Indonesia \\
\hline US(-1) & 0.023935 & $0.131017^{*}$ & $-0.17991^{*}$ & $0.087694^{*}$ & $-0.07958^{*}$ & $0.211211^{*}$ \\
\hline & {$[0.75093]$} & {$[6.07588]$} & {$[-7.03284]$} & {$[4.36818]$} & {$[-2.36408]$} & {$[6.65665]$} \\
\hline US(-2) & 0.044382 & 0.027768 & 0.041841 & 0.008661 & 0.056416 & 0.01854 \\
\hline & {$[1.39618]$} & {$[1.28419]$} & {$[1.59434]$} & {$[0.43114]$} & {$[1.67350]$} & {$[0.58085]$} \\
\hline Japan(-1) & -0.01565 & $-0.06726^{*}$ & 0.016346 & $-0.04887^{*}$ & -0.05711 & -0.0162 \\
\hline & {$[-0.48070]$} & {$[-3.94789]$} & {$[0.64276]$} & {$[-2.84879]$} & {$[-1.63399]$} & {$[-0.50508]$} \\
\hline Japan(-2) & -0.0365 & $-0.03224^{*}$ & 0.008403 & 0.002794 & -0.05066 & 0.001781 \\
\hline & {$[-1.18093]$} & {$[-1.93913]$} & {$[0.34221]$} & {$[0.16537]$} & {$[-1.52448]$} & {$[0.05684]$} \\
\hline Domestic(-1) & $-0.10243 *$ & 0.010151 & $-0.08479^{*}$ & $0.120908^{*}$ & 0.009948 & $0.162394 *$ \\
\hline & {$[-4.04279]$} & {$[0.57591]$} & {$[-3.61996]$} & {$[6.38994]$} & {$[0.41678]$} & {$[7.04987]$} \\
\hline Domestic(-2) & 0.015919 & 0.011649 & 0.019464 & -0.00223 & $-0.06726 *$ & -0.03029 \\
\hline & {$[0.63830]$} & {$[0.67121]$} & {$[0.85217]$} & {$[-0.11908]$} & {$[-2.84764]$} & {$[-1.33574]$} \\
\hline C & 0.000449 & $-4.13 E-06$ & $-0.00204^{*}$ & $-0.00051^{*}$ & -0.00064 & 0.000168 \\
\hline & {$[1.26002]$} & {$[-0.01954]$} & {$[-6.79233]$} & {$[-2.51434]$} & {$[-1.65470]$} & {$[0.45601]$} \\
\hline & & & & & & \\
\hline R-squared & 0.014046 & 0.015313 & 0.038408 & 0.022659 & 0.011978 & 0.049976 \\
\hline Adj. R-squared & 0.010044 & 0.01359 & 0.035407 & 0.020661 & 0.008892 & 0.046936 \\
\hline Sum sq. resids & 0.27537 & 0.522568 & 0.315367 & 0.354066 & 0.540679 & 0.473991 \\
\hline F-statistic & 3.509386 & 8.890029 & 12.80136 & 11.34116 & 3.881418 & 16.43923 \\
\hline Log likelihood & 4273.037 & 10231.05 & 5675.566 & 9101.429 & 5149.004 & 5127.303 \\
\hline Akaike AIC & -5.7455 & -5.9494 & -5.87416 & -6.18248 & -5.33403 & -5.44134 \\
\hline Schwarz SC & -5.72051 & -5.93689 & -5.85398 & -6.16824 & -5.31383 & -5.42074 \\
\hline Standard errors in $($ ) \& t-statistics in [ ], P-value* significant at 5\% & & \\
\hline & & & & & & \\
\hline
\end{tabular}

